の色差を求めるためであつて, 両軌跡の求め方は第 2 報汇記述した方法に依つた。

\section{結論}

（1）第 2 表より,色差の大きいものとして a と b, $3 \mathrm{a}$ と $3 \mathrm{c}, 3 \mathrm{~b}$ と $3 \mathrm{c}$, 小さいものとして a1 と b1, a1' $\mathrm{a} 1^{\prime}$ と $\mathrm{b} 1^{\prime}, \mathrm{a} 2$ と b2 が岕り，これは顔料生成の条件に 依つて結晶の形態が著しく異り，且同時に色が著しく 変化する事を示して居る。

（2）カップリング反応に於てデアゾニウム塩溶液 を急激に添加すると，顔料の結晶は小さく又写真に見 られる様な微小結晶の集合したものが見られる。こ の時顔料の沈降容積は小さく粉末の見掛壮比重は大き い。色は暗赤色で洉く見えるが粉末の色でも色相は余 り変らず (主波長にして $\operatorname{lm} \mu$ 程度), 刺㦸純度は小さ く，明度は著しく小さい。又淡色インキとした場合に はbとの差は小さくなり色相も殆んど変らない。

（3） a2, b2 の色が殆んぞ同じである事は a とbの 色の相異が化学的な組成の相違によるよりも形態の相 違に依る方が大きい事を示す。

（4）化学的な純度は色の刺㦸純度と何等関係はな い。

（5） a1'，b1'が他のものと較べて色相が違うのは
不純物の影響と考えられる。

（6）再結晶したものについても色の変化の起る事 は（3) の場合と同じである。又添加速度の早いものが 結晶が小さい事はカップリングの時と同じであり, 又 水の中に顔料溶液を添加する方が反対の順序の時より 遥かに小さい結晶を作る。

（7）粉末顔料とインキ中に分散した顔料とでは色 が同じ様な変化をしない。顔料は粉末のままで使用す る場合は稀であつて多くはベヒクルで分散した場合の 色が問題となる。又反射率曲線，或は $\log K / S$ 波長 の曲線に於ても特に低反射率の部分に於ける微小な変 化を見る事が困難である。このため以後に於て顔料の 色を見る場合，インキ或は亚鉛華で淡色インキとした ものの色を見る方が適当であると考える。

（8）色差の求め方としては第 2 表の三方法の中, 粉末の場合は別として, 淡色インキの場合明度（或 は塗膜の色の濃さ) が違えば色相も刺㦸純度も(従つ て Hue \& Chroma も) 大いに変る故正確な比較が 出来なくなる。(等明度の試料を作る事も技術的に困難 である）それ故第 2 報に記述せる方法に依つて標準と せる顔料の濃度変化に依る色度図上の色変化の軌跡を 求め等明度の標準試料との色差を求めるのが簡単で女。 り，又より合理的であると考えられる。

$667.622 .3: 668.811 .1: 535.66$

有機顏料の物理的性質（第 5 報）

\title{
I 色
}

（5） 0-トルエンーアゾー $\beta$-ナフトールの結晶形態変化と色の変化 Physical properties of organic pigments

I Color

(5) Pigment crystalls and color variation (o-Toluene-azo- $\beta$-naphthol)

佐 久間信 二*

緒言

前報同様の目的で試料として承醋酸に溶解し易く精 製及び結晶変化をみるのに便利なものとして，0ートル エンーアゾー $\beta$-ナフトールを採つた。尚, 原料 ○ートル イヂン及び $\beta$ ナフトールは不純物の影響をみるため 工業薬品を使用した。

\section{実験}

* 株式会社 山本化学研究所
試 料:

ßーナフトールは $\mathrm{mp}=116 \sim 120^{\circ} \mathrm{C}$, o-トルイヂンは 着色せるため蒸溜したが両者共工業薬品である。

ヂアゾ化及びカップリング反応は前報と同様に行い 得られた顔料を靬とす。

このものを以下の如く処理して顔料結晶の形態を変化 せしめ前報と同様乾燥したものを試料とする。

$\mathrm{a}: 7$ 部の水醋酸に依つて再結晶す。 $(\mathrm{mp}=128 \sim$

$\left.128.5^{\circ} \mathrm{C}\right)$

b : 上の再結晶液に水を加えて不純顔料を得。 
b 功邦 3 中に含まれる割合は $6.6 \%$ である。

$c: a$ を 20 部の水醋酸十 5 部の水より再結晶す。

$\mathrm{d}: \mathrm{a}$ を 15 部の氷醋酸に加熱溶解し, 多量の水中に

一侍浙入す。

e : a を 30 部の水醋酸に溶解し攪汼しつつ, これに水 200 部を約 1 時間を要して滴下し顔料を沈洪せしめる。 f: a を 100 部の水醋酸十25 部の水より再結晶す。

c〜f の濾液はすべて無色で顔料の融点は不変である。

結 果 :

各顔料の色は第 1 表, 第 1 図に示し $\log K / S$ 波長の曲線を第 2 図に示す。

邦3 を標準とした場合の各顔料の粉末及び淡色インキ 色差を第 2 表に示す。

第 1 表 各顔料粉末の色

\begin{tabular}{lcccccc} 
& $x$ & $y$ & $Y$ & $V_{X}-V_{Y}$ & $V_{Z}-V_{Y}$ & $V_{Y}$ \\
$\# 3$ & 0.6171 & 0.3456 & 0.1415 & 1.304 & -3.255 & 4.312 \\
\#3a & 0.6008 & 0.3476 & 0.1339 & 1.199 & -2.398 & 4.206 \\
\#3b & 0.3737 & 0.3521 & 0.0317 & 0.099 & -0.480 & 2.016 \\
\#3c & 0.5401 & 0.3521 & 0.1592 & 0.991 & -2.192 & 4.544 \\
\#3d & 0.6165 & 0.3517 & 0.1935 & 1.422 & -3.599 & 4.953 \\
\#3e & 0.5933 & 0.3511 & 0.1960 & 1.329 & -3.186 & 4.980 \\
\#3f & 0.5847 & 0.3451 & 0.1697 & 1.261 & -2.758 & 4.675 \\
& \multicolumn{7}{c}{ 淡色インキとし去場合の色 } \\
\#3 & 0.4190 & 0.3094 & 0.3391 & 0.932 & -0.757 & 6.320 \\
\#3a & 0.3969 & 0.3042 & 0.3081 & 0.900 & -0.530 & 7.030 \\
\#3b & 0.3619 & 0.3315 & $0.4349-0.369$ & -1.055 & 6.065 \\
\#3c & 0.3810 & 0.3069 & 0.4730 & 0.760 & -0.448 & 7.284 \\
\#3d & 0.3968 & 0.3097 & 0.4100 & 0.845 & -0.640 & 6.855 \\
\#3e & 0.3994 & 0.3078 & 0.4327 & 0.859 & -0.596 & 7.014 \\
\#3f & 0.3766 & 0.3056 & 0.4555 & 0.714 & -0.389 & 7.169
\end{tabular}

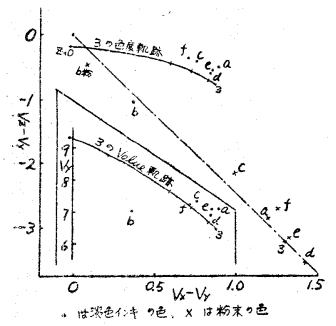

第 1 図

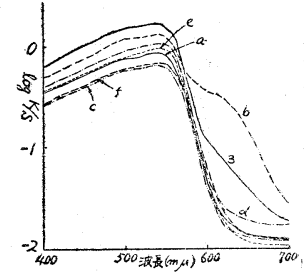

第 2 図
第 2 表 到標準とした時の色差

$\begin{array}{ccc}\begin{array}{c}\text { 粉末の } \\ \text { 色差 }\end{array} & \begin{array}{c}\text { 淡色イン } \\ \text { キの色差 }\end{array} & \begin{array}{c}\text { 同左: (但, 等 } \\ \text { 明席で比較) }\end{array} \\ 7.2 & 7.6 & 6.7 \\ 69.0 & 48.3 & 17.2 \\ 21.3 & 12.3 & 3.9 \\ 9.4 & 6.3 & 2.5 \\ 6.3 & 7.5 & 4.5 \\ 8.8 & 13.1 & 3.1\end{array}$

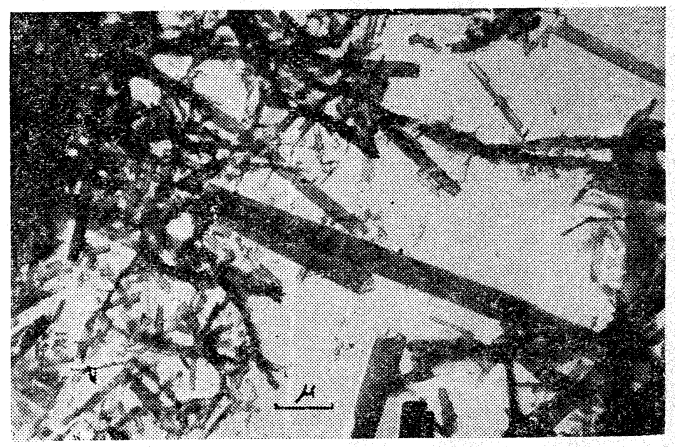

$3 \times 10000$
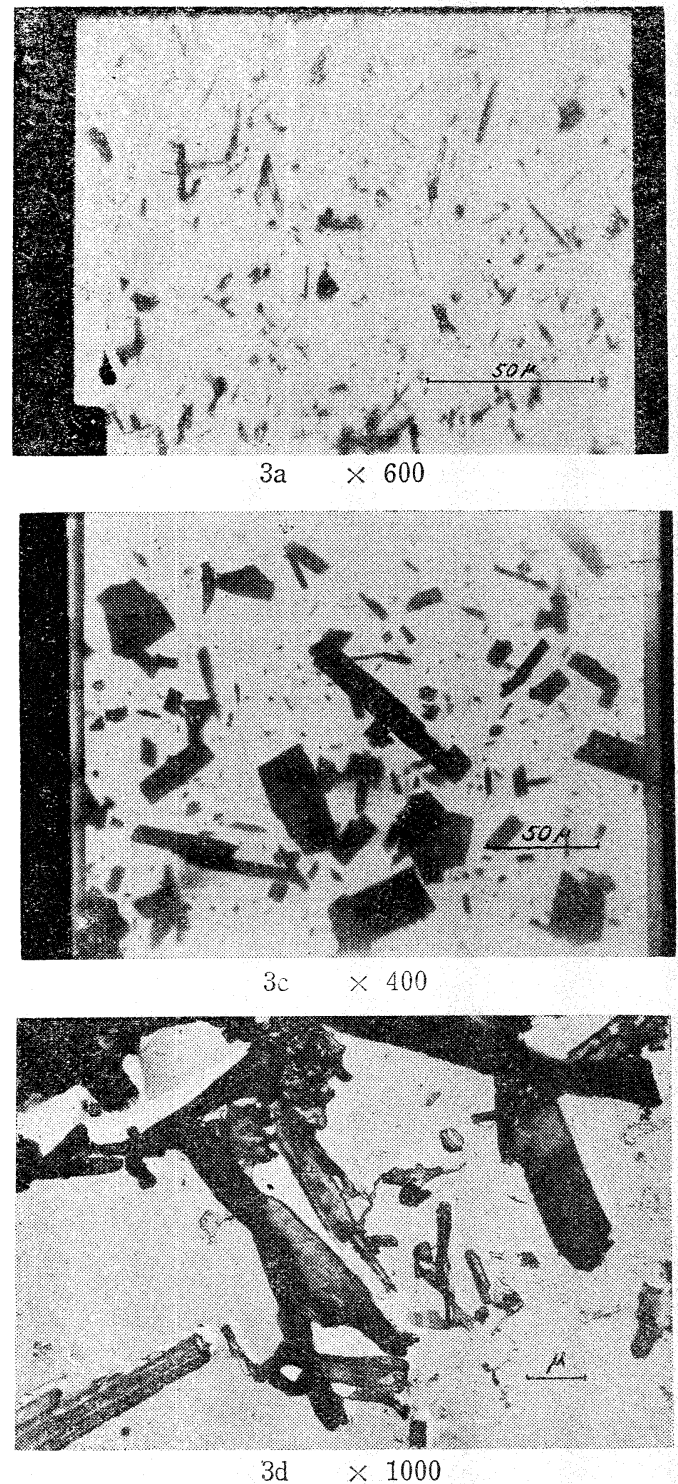


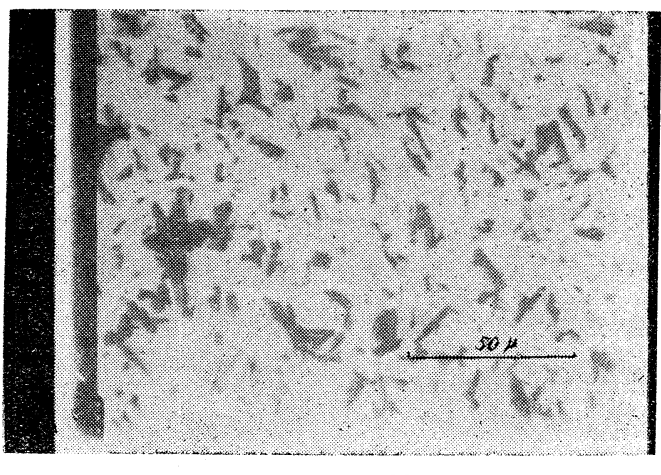

$3 \mathrm{e} \times 600$

結

論

前報と同様の事が見られるぶ，又

(1) 不純な顔料 b 及びこれを $6.6 \%$ 含有する靬 の色は $\log K / S$ 波長の曲線沉いては他のものと明 瞭に異るが，色度図及び色差の表については純烧な顔

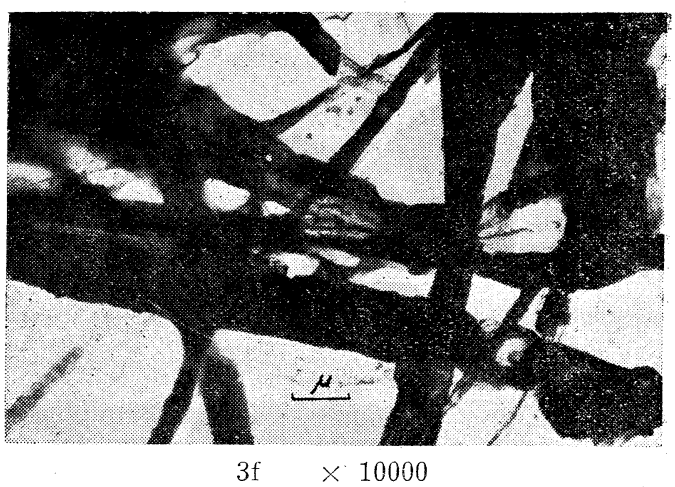

料同志の色差儿比較して非常に大きいとは言えない。

（2）顔料の結晶形態は顔料生成の条件に依つて大 さく変化し, 同時氾色の变化子見られるが, 两者の関 倸注簡単でない。

(3) $\log K / S$ 波長の曲線に於て $(\log K / S)_{\text {max }}$ 一 $(\log K / S)_{\min }$ の值は大体刺㦸純度と同一関係にある。

$678.7 .01: 639.5: 667.622$

顏料添加に依万合成高分子物溶液の粘度变化に就いて

土屋昌 子*

要 旨

代表的な 3 種又は 4 種の顔料炎，性質の異つた合成 高分子物の溶液で混和した場合の溶液粘度の变化を比 較的稀薄な溶液で測定した。

今までの塗料の製造工程では，使用する顔料の吸油 量が重要視されて居るにも拘わらず，合成樹脂塗料に 於いては，顔料の吸油量と混和性の関係があまりはつ きりしていないようであるが，ここで行つた予備実験 の結果でもわかるように，かなりの重要性があるよ5 に思われる。

また, ポリマーの極性, 非梷性も粘度の上り方に影 響をあたえることが多とめられた。

このようにして認められた顔料添加による合成高分 子物溶液の粘度変化と, これを皮膜にした場合の顔料 粒子の凝集性との関連も一，二のポリマー，顔料につ いて夹験した処によると，定性的な結杲ではもるが， 粘度上杽割合の大きいるの程，皮膜の表面が粗雑であ つて顔料の凝集性が大きいように思われた。

* 京都大学化学研究所, 格四砳焭室
緒言

塗料工業では顔料をべとクル溶液と混和する工程が 重要である。今までは顔料の粒子の分散性や安定性は 勿論の事であるが，出来上り塗料のいろいろな流動性 を測定する事に依つて，顔料とベヒクル溶液との混和 性が深く研究されて来た。殊に顔料の吸油量と混和性 の関係なども重要な事柄として研究されて居る。

最近では, 種々の合成樹脂が塗料べヒクルとして活 用されはじめている。この場合に合成樹脂の吟味に於 いては主として出来上り叙膜の物理的並びに化学的の 性質が考えられているに過ぎない。

合成樹脂ベヒクルに於いても，今までの場合と同様 に顔料の吸油量がべヒクル溶液と顔料の混和性に大き な影響をもつているものと思われるがをだはつきりし た研究はないようである。

ここでは性質の異つた合成高分子物の溶液と顔料の 種々の組合せによる粘度変化を測定してみた。

\section{実験及び結果}

（1）ヂオキサンを溶剂にした場合 